\title{
The less things change, the more they are different: contributions of long-term synaptic plasticity and homeostasis to memory
}

\author{
Samuel Schacher ${ }^{1}$ and Jiang-Yuan $\mathrm{Hu}$ \\ Department of Neuroscience, Columbia University College of Physicians and Surgeons, New York State Psychiatric Institute, New York, \\ New York 10032, USA
}

\begin{abstract}
An important cellular mechanism contributing to the strength and duration of memories is activity-dependent alterations in the strength of synaptic connections within the neural circuit encoding the memory. Reversal of the memory is typically correlated with a reversal of the cellular changes to levels expressed prior to the stimulation. Thus, for stimulus-induced changes in synapse strength and their reversals to be functionally relevant, cellular mechanisms must regulate and maintain synapse strength both prior to and after the stimuli inducing learning and memory. The strengths of synapses within a neural circuit at any given moment are determined by cellular and molecular processes initiated during development and those subsequently regulated by the history of direct activation of the neural circuit and system-wide stimuli such as stress or motivational state. The cumulative actions of stimuli and other factors on an already modified neural circuit are attenuated by homeostatic mechanisms that prevent changes in overall synaptic inputs and excitability above or below specific set points (synaptic scaling). The mechanisms mediating synaptic scaling prevent potential excitotoxic alterations in the circuit but also may attenuate additional cellular changes required for learning and memory, thereby apparently limiting information storage. What cellular and molecular processes control synaptic strengths before and after experience/activity and its reversals? In this review we will explore the synapse-, whole cell-, and circuit level-specific processes that contribute to an overall zero sum-like set of changes and long-term maintenance of synapse strengths as a consequence of the accommodative interactions between long-term synaptic plasticity and homeostasis.
\end{abstract}

Long-term changes in the strength of synapses-long-term potentiation/facilitation (LTP or LTF) and long-term depression (LTD)_ are critical cellular mechanisms in modulating the amplitude and duration of behavioral modifications or the storage of memories (Kandel 2001). These synaptic changes could lead to significant and long-lasting bidirectional changes in the excitability of some neurons within a neural circuit, which under extreme circumstances can lead to excitotoxic or degenerative consequences that impact on cell function or survival, or the storage of memory (Abbott and Nelson 2000; Nelson and Turrigiano 2008). To prevent these maladaptive processes, homeostatic mechanisms restrain the overall weights of synaptic inputs and excitation/ inhibition balance to ensure that neurons remain functional (including the ability to express additional activity-dependent plasticity) while the storage of information acquired by previous activity is maintained (Davis 2006; Marder and Goaillard 2006; Roth-Alpermann et al. 2006; Ibata et al. 2008; Kim and Tsien 2008; Turrigiano 2008).

The mechanisms mediating synaptic scaling/homeostasis at the level of individual neurons include those that regulate presynaptic transmitter release by affecting structure/function properties of the presynaptic terminals (Burrone et al. 2002; Frank et al. 2006, 2009; Branco et al. 2008; Han and Stevens 2009), regulate postsynaptic responses by modulating the expression and localization of transmitter receptors at synaptic or extrasynaptic sites (Turrigiano et al. 1998; Perez-Otano and Ehlers 2005; Chowdhury et al. 2006; Shepherd et al. 2006; Hou et al. 2008,

\footnotetext{
'Corresponding author

E-mail sms2@columbia.edu

Article is online at http://www.learnmem.org/cgi/doi/10.1101//m.027326.112.
}

2011; Gainey et al. 2009), or regulate intrinsic excitability by modulating voltage-gated or transmitter-gated ion channels (Desai et al. 1999; Campanac et al. 2008; Grubb and Burrone 2010; O'Leary et al. 2010; Fortin et al. 2012; Lee 2012; Driscoll et al. 2013). At the wider network level, mechanisms that impact on more global changes, such as the balance of excitatory and inhibitory synaptic inputs, could restrain overall excitability to more acceptable levels (Chang et al. 2010; Isaacson and Scanziani 2011; Campanac et al. 2012).

However, some of the cellular mechanisms enumerated above that restrain synapse strengths or neuron and circuit level excitability to maintain homeostasis also contribute to longterm synaptic plasticity that underlies learning and memory. Activity-dependent alterations in the structure/function of the presynaptic terminals, postsynaptic receptor expression/distribution, and changes in intrinsic excitability are cellular correlates mediating learning and memory (Dale et al. 1987; Bailey and Chen 1988a,b; Bailey et al. 1992; Zhu et al. 1997; Luscher et al. 1999; Malinow and Malenka 2002; Bredt and Nicoll 2003; Zhang and Linden 2003; Frick et al. 2004; Matsuzaki et al. 2004; Montgomery and Madison 2004; Bastrikova et al. 2008; Bourne and Harris 2011; Sanders et al. 2012; Raynaud et al. 2013). Moreover, the reversal of the cellular changes mediating shortterm or long-term memory as a result of inactivity or other forms of convergent activity results in the reversal of synaptic change to

\footnotetext{
C 2014 Schacher and Hu This article is distributed exclusively by Cold Spring Harbor Laboratory Press for the first 12 months after the full-issue publication date (see http://learnmem.cshlp.org/site/misc/terms.xhtml). After 12 months, it is available under a Creative Commons License (AttributionNonCommercial 3.0 Unported), as described at http://creativecommons. org/licenses/by-nc/3.0/.
} 
levels closer to those expressed prior to the experience/activity that induced the initial cellular changes. How do the competing mechanisms of synaptic scaling and synaptic plasticity interact at the cellular and network level and how does that interaction influence levels of synaptic transmission prior to and after activity that evokes long-term plasticity?

The compartmentalization of synaptic plasticity to specific connections and within specific neuronal populations is one critical mechanism for reducing the potential for runaway plasticity that would impact negatively on the integrity of synaptic connections and cell survival and at the same time facilitate information storage. Limiting the population of neurons and synapses expressing one type of long-term synaptic change that contributes to the storage of a particular memory could be effectuated by a combination of processes that include the selective tagging of activated (or inactive) synapses for long-term change. This can be accomplished through: (1) activity-dependent post-translational modifications of synaptic proteins at the activated synapses and at nearby synapses experiencing different levels of activity; (2) local protein synthesis and degradation at synapses that are regulated by activity; and (3) zero-sum forms of local plasticity that alter activated synapses at the expense of neighboring synapses experiencing different levels of activity. Thus, cellular correlates of memory storage may reside in relatively modest numbers of synapse-specific modifications-selective strengthening and weakening of nearby synapses converging on a common target.

The changes at these synapses are consolidated by activitydependent changes in gene expression in the cell body and cellwide protein synthesis along with long-term synaptic scaling at both the cellular and network level that balance excitatory and inhibitory synaptic interactions and overall neuronal excitability. The combination of these two processes would contribute to the maintenance of the new level of synaptic strengths at specific synapses and the excitatory/inhibitory balance within the network encoding the memory until additional forms of activity induce new bidirectional changes in synapse strength and excitability. Restraining persistent synaptic changes that are required for encoding a long-term memory to a relatively modest number of specific synapses through the accommodative interactions between plasticity and homeostasis would increase the information storage capacity of the network. The fewer the connections that need to be altered in a particular direction for the storage of a memory (the less things change) would leave more connections for additional stimulus-induced alterations for the storage of other memories (the more things can be different).

\section{Sparse neuronal coding of information}

How many neurons and their synaptic connections participate in the encoding of a specific memory or piece of information? Although the answer to this question is unknown, a few cases suggest that this coding is relatively sparse. Contextual fear conditioning in rodents and relatively simple forms of short- and long-term behavioral modifications in invertebrates, such as Aplysia, suggest that changes in a small number of neurons and their synapses contribute to the memory. A relatively small population of neurons in the basal lateral nuclear complex of the amygdala (BLA) participates in the storage and recall of contextual fear memory (Han et al. 2007; Reijmers et al. 2007). In Aplysia, although stimuli that induce long-term sensitization of defensive reflexes or adaptive changes in feeding behavior activate many neurons (Zecevic et al. 1989; Cropper et al. 2004; Nargerot and Simmers 2012), the functional and structural changes in a small population of neurons encode most of the information accounting for the long-term changes in behavior (Bailey and Chen 1988a,b; Brembs et al. 2002; Baxter and Byrne 2006; Nargerot and Simmers 2012). This funneling of cellular plasticity to selective populations of neurons and synapses requires cellular mechanisms that allow for the targeting of the cellular changes to specific neurons and synapses. The changes that encode the persistence of the memory need not be expressed at once but can emerge within a selective population of neurons or synapses over time as a result of sequential cascades initiated by the stimuli inducing the adaptive change in the nervous system, which is then followed by other forms of activity that contribute to consolidation (Casadio et al. 1999; Hu et al. 2011). Such neuron- and synapse-specific changes can be produced by several processes working simultaneously: (1) synaptic tagging, (2) local activitydependent regulation of protein synthesis and degradation, and (3) long-lasting forms of one type of plasticity at specific activated synapses at the expense of neighboring synapses activated (or not activated) with different stimuli.

\section{Synaptic tagging}

Most neurons receive convergent synaptic inputs from multiple sources where each input is capable of expressing autonomous forms of short- and long-term plasticity (Clark and Kandel 1993; Frey and Morris 1997; Martin et al. 1997). Synapse-specific forms of long-term plasticity are expressed despite changes in gene expression and the synthesis of plasticity-related proteins that are capable of reaching all parts of the activated neurons (Kandel 2001; Alarcon et al. 2006; Govindarajan et al. 2006; Doyle and Kiebler 2011; Redondo and Morris 2011). The tagging of activated synapses for subsequent expression of persistent plasticity is independent of macromolecular synthesis and relies on activity-dependent activation of post-translational modification enzymes such as kinases, ubiquitin-mediated degradation pathways, or other pathways (Lisman et al. 2002; Miller et al. 2002; Ehlers 2003; Fonseca et al. 2006; Huang et al. 2006; Young et al. 2006; Wayman et al. 2008; Redondo et al. 2010; Ishikawa et al. 2011; Okuno et al. 2012).

The "tagging" of specific synapses for long-lasting modification is short-lived. Weak stimuli given to neighboring synapses that are sufficient to produce a transient form of LTP or LTD (E-LTP or E-LTD) or short-term plasticity will "capture" longerlasting forms of plasticity if the weaker activity is presented within an hour or so of the stronger stimuli to neighboring synapses that result in the expression of macromolecular synthesis-dependent forms of long-term plasticity (Frey and Morris 1997; Martin et al. 1997).

The spread of plasticity in most cases covers a relatively short distance (depending on the strength of the stimuli that induce the longer lasting forms of plasticity) and can be dendritic branchspecific (Engert and Bonhoeffer 1997; Wang et al. 2003; Alarcon et al. 2006; Huang et al. 2006; Young et al. 2006; Harvey and Svoboda 2007; Sajikumar et al. 2007). Thus neighboring synapses receiving inputs of various strengths do not act independently but express a form of metaplasticity based on relative timing of activation, stimulus strength, and distance from other stimulus-activated synapses. This provides a basis of information storage at restricted sets of synapses whose functional states are linked by time and strength of activation and topographic location within the circuit (Huang et al. 1992; Govindarajan et al. 2006; Rabinowitch and Segev 2006, 2008; Harvey and Svoboda 2007).

Synapses tagged for potential expression of L-LTP vs. L-LTD must be able to "capture" the appropriate molecules to express the cellular changes mediating the long-lasting bidirectional changes in synapse strength. Support for this notion comes from results indicating the "cross-tagging" of long-term plasticity (Sajikumar and Frey 2004; Frey and Frey 2008; Ishikawa et al. 
2011). Weak stimuli that by themselves will evoke E-LTD, will lead to the expression of L-LTD at those synapses when the stimuli are presented shortly before or after neighboring synapses receive stimulation that produces L-LTP. The same phenomenon occurs with conversion to L-LTP at synapses given a weak stimulus that evokes E-LTP before or after other nearby inputs experience stimulation that evoke L-LTD. The implication of this cross-tagging phenomenon is that molecules permissive for persistent plasticity (L-LTP or L-LTD) are synthesized (cell body and/or in nearby synapses induced by appropriate stimuli) and then transported to synapses that have been primed to capture the appropriate subset of molecules to express either L-LTP (local stimuli that produce E-LTP) or L-LTD (local stimuli that produce E-LTD). How are specific synapses tagged and then subsequently capable of capturing the appropriate set of proteins to express the appropriate form of persistent plasticity?

\section{Activity-dependent regulation of local protein synthesis}

Long-lasting forms of plasticity require new protein synthesis and in most cases also require new transcription (Kandel 2001). With the discovery of specific mRNAs and the machinery for protein synthesis at distal dendrites (Steward and Levy 1982), growth cones (Lin and Holt 2007), and axon terminals (Bassell and Warren 2008; Wang et al. 2009), the importance of activitydependent regulation of local synthesis of plasticity-related proteins in the expression of synapse-specific long-term plasticity gained general acceptance. Either in the presence or absence of cell bodies, long-lasting forms of plasticity in hippocampal neural circuits (Kang and Schuman 1996; Huber et al. 2000; Cracco et al. 2005; Karpova et al. 2006; Cajigas et al. 2010; Redondo et al. 2010) and at Aplysia sensorimotor synapses (Martin et al. 1997; Casadio et al. 1999; Hu et al. 2004; Wang et al. 2009) depend on protein synthesis at or near synaptic sites. Stimuli that induce LTP or LTF, or LTD remove translation repression on mRNAs that accumulate at distal sites and activate local translation factors through various signaling pathways (Linden 1996; Wu et al. 1998; $\mathrm{Hu}$ et al. 2004; Govindarajan et al. 2006; Raab-Graham et al. 2006; Bassell and Warren 2008; Doyle and Kiebler 2011; Kandel 2012; Udagawa et al. 2012). Many of the proteins synthesized locally or transported from the cell body contribute to either LTP or LTD depending on the type of plasticity and tag initiated locally. Thus in "cross-tagging" situations, proteins synthesized at local synapses or transported from the cell body of the activated neuron following stronger stimuli that would lead to long-lasting plasticity could convert neighboring synapses experiencing a weaker stimulus to express a long-lasting plasticity. Thus synapses stimulated to express L-LTP could lead to the synthesis of proteins that are permissive to convert neighboring synapses to express any form of long-lasting plasticity if those synapses were stimulated with the appropriate stimuli that produce either E-LTD or E-LTP shortly before or after the stronger stimuli (Sajikumar and Frey 2004; Frey and Frey 2008; Ishikawa et al. 2011). Long-lasting plasticity is accompanied by functional and structural changes at specific synapses; L-LTD is accompanied by the silencing and/or elimination of synaptic sites, while L-LTP or LTF is accompanied by the strengthening and/or formation of new synaptic sites (Glanzman et al. 1990; Bailey et al. 1992; Casadio et al. 1999; Bastrikova et al. 2008; Bourne and Harris 2011). Thus, when multiple forms of synaptic plasticity are expressed at neighboring synaptic sites, the net consequence (L-LTP + L-LTD) could maintain structural and functional homeostasis as specific sets of synapses are formed or strengthened and others nearby are silenced or eliminated.
Molecules associated with the tagging and capture of L-LTP vs. L-LTD and the newly synthesized proteins (local or transported from the cell body) that result in the expression of L-LTP vs. L-LTD are beginning to be identified. Increases in the activation of neurotrophins and their receptors (BDNF and trkB receptors) and up-regulation of their expression and local distribution at synapses expressing E-LTP will lead to changes in local protein synthesis and the expression of L-LTP (Lu et al. 2011; Sajikumar and Norte 2011; Fortin et al. 2012). Local activation of specific kinases and their anchoring or interaction with other plasticity-related proteins could convert E-LTP (PKA, PKM $\zeta$, and some forms of CaM kinases) or E-LTD (other CaM kinases and MAPK) to longer lasting forms (Sajikumar et al. 2005, 2007; Alarcon et al. 2006; Huang et al. 2006; Young et al. 2006; Sajikumar and Norte 2011). The accumulation of Arc/Arg3.1 at weakened synapses (as those expressing E-LTD) and its interaction with CamKIIß promotes AMPA receptor endocytosis (Chowdhury et al. 2006; Rial Verde et al. 2006; Waung et al. 2008; Redondo et al. 2010; Okuno et al. 2012) and could contribute to the expression of L-LTD at those synapses while others nearby express L-LTP. Selective activation of proteolytic processes, such as activation of neuropsin or the ubiquitin-proteasome pathway (Bingol and Schuman 2006; Fonseca et al. 2006; Cai et al. 2010; Ishikawa et al. 2011) may contribute to the selective accumulation of newly synthesized plasticity-related proteins to produce the expression of either L-LTP or L-LTD. In Aplysia, the local synthesis of the neuropeptide sensorin and activation of its signaling pathway by PKA phosphorylation may initiate and maintain the local expression of LTF (Hu et al. 2004, 2011). In addition, synaptic tagging and capture may also facilitate the local accumulation of mRNAs at activated synapses for subsequent maintenance of the long-lasting plasticity (Steward et al. 1998; Sun et al. 2001; Moccia et al. 2003; Grooms et al. 2006; Waung et al. 2008; Doyle and Kiebler 2011; Lu et al. 2011; Fortin et al. 2012). The overall consequence of local tagging, protein synthesis and degradation, transport and capture, and mRNA transport and capture would be to focus the appropriate functional and morphological expression of longterm plasticity at specific synapses. What other constraints lead to local expression of plasticity?

\section{Local expression of zero-sum long-term plasticity}

The strengths of synaptic connections in neocortex vary significantly (Feldmeyer and Sakmann 2000; Sarid et al. 2007) -as much as 30-fold-thereby influencing the expression of different forms of plasticity from L-LTP through L-LTD with shorter-lasting protein synthesis-independent forms of plasticity in between. Because of tagging and capture and cross-tagging phenomena described above, the final topography of the plasticity will vary due to the nature of the stimuli and the initial state of function of each synaptic site prior to the stimuli. The specific state expressed at each synaptic site, shaped by development and previous history of activation, will vary from silent synapses (low probability of transmitter release or receptor activation) to synapses with high release probability (large or multiple active zones packed with synaptic vesicles) that are aligned with large postsynaptic elements containing a high density of postsynaptic receptors (Montgomery and Madison 2004). The former will respond best to stimuli producing synaptic enhancement while the latter will respond best to stimuli producing synaptic depression as a result of floor and ceiling effects, respectively, that are regulated by homeostatic processes expressed both at the cell-wide level and at individual synapses (Burrone et al. 2002; Royer and Pare 2003; Thiagarajan et al. 2005; Rabinowitch and Segev 2006; Roth-Alpermann et al. 2006; Harvey and Svoboda 2007; Seeburg 
et al. 2008; Beique et al. 2011; Arendt et al. 2013). Activity might induce L-LTP foci that are bounded by L-LTD foci initiated by synaptic tagging, capture, and cross-tagging through activitydependent activation of appropriate kinases and other posttranslational modification enzymes, local protein synthesis, and/ or degradation followed by transport of additional proteins from the cell bodies of the activated neurons.

Additional sharpening of plasticity at the circuit level is provided by differential expression of long-term plasticity (either LTP or LTD, both forms or neither form) at excitatory inputs with specific populations of inhibitory (GABA) interneurons (Chang et al. 2010; Nissen et al. 2010; Sarih et al. 2012). The selective expression of long-term plasticity at these inputs can reduce potential excitotoxic consequences of the activity-dependent plasticity mediating learning and memory expressed by the neurons of the circuit encoding the memory (Lamsa et al. 2007; Isaacson and Scanziani 2011).

The consolidation of persistent forms of plasticity at specific synaptic sites would entail structural/functional changes including the formation or elimination of postsynaptic spines and presynaptic elements, and the localization of critical proteins expressed through the net changes in protein synthesis and degradation required for the permanent expression of the new synaptic states (Hegde et al. 1993; Chain et al. 1999; Bingol and Schuman 2006; Karpova et al. 2006; Cajigas et al. 2010; Chen et al. 2011; Hou et al. 2011). Neighboring zones of synaptic sites would thus express either L-LTP or L-LTD initiated by earlier molecular processes in the activated terminals coupled with the acquisition of new macromolecules. The levels of spontaneous release of conventional neurotransmitters (glutamate) or other factors (neurotrophins or cytokines) expressed at each synapse as a consequence of the activity-induced plasticity might maintain appropriate levels of local synthesis required for local forms of L-LTP and L-LTD (Sutton et al. 2004, 2006). The molecules affecting synaptic strength at any moment in time could represent presynaptic proteins and signaling pathways critical for transmitter release (Gonzalez-Forero et al. 2012), postsynaptic transmitter receptors, and proteins participating in their cycling into and out of the plasma membrane (Malinow and Malenka 2002; Fortin et al. 2012), neurotrophins and other secreted factors and their receptors (English et al. 2012; Hruska and Dalva 2012), factors or regulators of protein translation and degradation (Cajigas et al. 2010; Kandel 2012), and kinases that are constitutively active (Chain et al. 1999; Hernandez et al. 2003). These local molecules and their downstream signaling coupled with proteins and mRNA transported from the cell body would maintain the new level of synaptic transmission that encodes the behavioral modification or memory. Disruption of specific components associated with the maintenance of this new level of synaptic transmission would then lead to reversals in synaptic strengths toward the original prestimulus state. What might regulate basal levels of synaptic transmission before and after induction or reversals of long-term plasticity?

\section{Coexpression of homeostatic and plasticity mechanisms regulate basal synaptic transmission}

Reversal of short- and long-term plasticity or short- and long-term memory typically results in the reversal of synaptic strengths or behavior toward prestimulus levels. This reversal of synaptic strength toward earlier baselines is likely to be the outcome of hierarchic and constitutive cellular processes initiated during development and consolidated in early postnatal life that defines a basal level of circuit function that is subsequently coexpressed with additional cellular processes that regulate bidirectional changes in this set point of circuit function to accommodate environmental contingencies in the form of learning and memory (Hubel and Wiesel 1970; Desai et al. 2002; Turrigiano and Nelson 2004; Huupponen et al. 2007; Petrus et al. 2011; Ransom et al. 2012). Disruptions of the cellular processes associated with the activity/experience-dependent change in function might allow the initial constitutive homeostatic processes to restore synaptic strengths to previous levels.

The hierarchic organization of the constitutive process that defines basal level of synaptic strength would include the participation of molecules and pathways required for inducing and maintaining synaptic plasticity following activity. Maintenance of synaptic strength is affected by (1) transcription factors (Chao et al. 2007; Liu et al. 2011), (2) activity regulating local synthesis, degradation, and distribution of Arc/Arg3.1 and glutamate receptors (Cajigas et al. 2010; Beique et al. 2011; Chen et al. 2011), (3) constitutive actions of secreted factors, such as neurotrophins, cytokines, and ephrins, acting on their receptors to regulate structural and functional integrity of the synapses (Hu et al. 2004, 2011; Goold and Davis 2007; Frank et al. 2009; English et al. 2012; Hruska and Dalva 2012), and (4) the persistent activation of signaling cascades by kinases such as CaM kinases and PKM $\zeta$ that affect levels of modifications in critical presynaptic and postsynaptic proteins throughout the circuit (Lisman et al. 2002; Sajikumar et al. 2005). Cytokines such as TNF $\alpha$ up-regulate AMPA receptor distribution following prolonged blockade of activity (Stellwagen and Malenka 2006), while regulation of the expression of dybindin or other cytokines and their receptors affects presynaptic transmitter release (Goold and Davis 2007; Dickman and Davis 2009). Future experiments need to test the time course of expression of these or similar molecules before and after activity-dependent persistent plasticity and its reversal and whether the timely removal or up-regulation of these molecules or their activity would affect the reestablishment of synaptic strength following conditions that are known to reverse long-term memory or synaptic plasticity.

\section{Acknowledgments}

We thank Amir Levine and Larry Abbott for their helpful advice, discussions, and comments. The authors are supported by NIH grant MH060387.

\section{References}

Abbott LF, Nelson SB. 2000. Synaptic plasticity: Taming the beast. Nat Neurosci 3: 1178-1183.

Alarcon JM, Barco A, Kandel ER. 2006. Capture of the late phase of long-term potentiation within and across the apical and basilar dendritic compartments of CA1 pyramidal neurons: Synaptic tagging is compartment restricted. J Neurosci 26: 256-264.

Arendt KL, Sarti F, Chen L. 2013. Chronic inactivation of a neural circuit enhances LTP by inducing silent synapse formation. J Neurosci 33: 2087-2096.

Bailey CH, Chen M. 1988a. Long-term memory in Aplysia modulates the total number of varicosities of single identified sensory neurons. Proc Natl Acad Sci 85: 2373-2377.

Bailey CH, Chen M. 1988b. Long-term sensitization in Aplysia increases the number of presynaptic contacts onto the identified gill motor neuron L7. Proc Natl Acad Sci 85: 9356-9359.

Bailey CH, Chen M, Montarolo PG, Kandel ER, Schacher S. 1992. Inhibitors of protein and RNA synthesis block structural and functional changes accompanying long-term synaptic facilitation and inhibition in Aplysia sensory neurons. Neuron 9: 749-758.

Bassell GJ, Warren ST. 2008. Fragile X syndrome: Loss of local mRNA regulation alters synaptic development and function. Neuron 60: 201-214.

Bastrikova N, Gardner GA, Reece JM, Jeromin A, Dudek SM. 2008. Synapse elimination accompanies functional plasticity in hippocampal neurons. Proc Natl Acad Sci 105: 3123-3127.

Baxter DA, Byrne JH. 2006. Feeding behavior of Aplysia: A model system for comparing cellular mechanisms of classical and operant conditioning. Learn Mem 13: 669-680. 
Beique JC, Na Y, Kuhl D, Worley PF, Huganir RL. 2011. Arc-dependent synapse-specific homeostatic plasticity. Proc Natl Acad Sci 108: $816-821$.

Bingol B, Schuman EM. 2006. Activity-dependent dynamics and sequestration of proteasomes in dendritic spines. Nature 441: $1144-1148$.

Bourne JN, Harris KM. 2011. Coordination of size and number of excitatory and inhibitory synapses results in a balanced structural plasticity along mature hippocampal CA1 dendrites during LTP. Hippocampus 21: $354-373$.

Branco T, Staras K, Darcy KJ, Goda Y. 2008. Local dendritic activity sets release probability at hippocampal synapses. Neuron 59: 475-485.

Bredt DS, Nicoll RA. 2003. AMPA receptor trafficking at excitatory synapses. Neuron 40: $361-379$

Brembs B, Lorenzetti FD, Reyes FD, Baxter DA, Byrne JH. 2002. Operant reward learning in Aplysia: Neuronal correlates and mechanisms. Science 296: 1706-1709.

Burrone J, O'Byrne M, Murthy VN. 2002. Multiple forms of synaptic plasticity triggered by selective suppression of activity in individual neurons. Nature 420: 414-418.

Cai F, Frey JU, Sanna PP, Behnisch T. 2010. Protein degradation by the proteasome is required for synaptic tagging and the heterosynaptic stabilization of hippocampal late phase long-term potentiation. Neuroscience 169: 1520-1526.

Cajigas IJ, Will T, Schuman EM. 2010. Protein homeostasis and synaptic plasticity. ЕMBO J 29: 2746-2752.

Campanac E, Daoudal G, Ankri N, Debanne D. 2008. Downregulation of dendritic I(h) in CA1 pyramidal neurons after LTP. J Neurosci 28: $8635-8643$.

Campanac E, Gasselin C, Baude A, Gama S, Ankri N, Debanne D. 2012. Enhanced intrinsic excitability in basket cells maintains excitatoryinhibitory balance in hippocampal circuits. Neuron 77: 712-722.

Casadio A, Martin KC, Giustetto M, Zhu H, Chen M, Bartsch D, Bailey CH, Kandel ER. 1999. A transient, neuron-wide form of CREB-mediated long-term facilitation can be stabilized at specific synapses by local protein synthesis. Cell 99: 221-237.

Chain DG, Casadio A, Schacher S, Hegde AN, Valbrun M, Yamamoto N, Goldberg AL, Bartsch D, Kandel ER, Schwartz JH. 1999. Mechanisms for generating the autonomous cAMP-dependent protein kinase required for long-term facilitation in Aplysia. Neuron 22: 147-156.

Chang MC, Park JM, Pelkey KA, Grabenstatter HL, Xu D, Linden DJ, Sutula TP, McBain CJ, Worley PF. 2010. Narp regulates homeostatic scaling of excitatory synapses on parvalbumin-expressing interneurons. Nat Neurosci 13: 1090-1097.

Chao HT, Zoghbi HY, Rosenmund C. 2007. MeCP2 controls excitatory synaptic strength by regulating glutamatergic synapse number. Neuron 56: $58-65$.

Chen PC, Bhattacharyya BJ, Hanna J, Minkel H, Wilson JA, Finley D, Miller RJ, Wilson SM. 2011. Ubiquitin homeostasis is critical for synaptic development and function. J Neurosci 31: 17505-17513.

Chowdhury S, Shepherd JD, Okuno H, Lyford G, Petralia RS, Plath N, Kuhl D, Huganir RL, Worley PF. 2006. Arc/Arg3.1 interacts with the endocytic machinery to regulate AMPA receptor trafficking. Neuron 52: 445-459.

Clark GA, Kandel ER. 1993. Induction of long-term facilitation in Aplysia sensory neurons by local application of serotonin to remote synapses. Proc Natl Acad Sci 90: 11411-11415.

Cracco JB, Serrano P, Moskowitz SI, Bergold PJ, Sacktor TC. 2005. Protein synthesis-dependent LTP in isolated dendrites of CA1 pyramidal cells. Hippocampus 15: 551-556.

Cropper EC, Evans CG, Hurwitz I, Jing J, Proekt A, Romero A, Rosen SC. 2004. Feeding neural networks in the mollusc Aplysia. Neurosignals 3: $70-86$.

Dale N, Kandel ER, Schacher S. 1987. Serotonin produces long-term changes in the excitability of Aplysia sensory neurons in culture that depend on new protein synthesis. J Neurosci 7: 2232-2238.

Davis GW. 2006. Homeostatic control of neural activity: From phenomenology to molecular design. Annu Rev Neurosci 29: 307-323.

Desai NS, Rutherford LC, Turrigiano GG. 1999. Plasticity in the intrinsic excitability of cortical pyramidal neurons. Nat Neurosci 2: 515-520.

Desai NS, Cudmore RH, Nelson SB, Turrigiano GG. 2002. Critical periods for experience-dependent synaptic scaling in visual cortex. Nat Neurosci 5: $783-790$

Dickman DK, Davis GW. 2009. The schizophrenia susceptibility gene dysbindin controls synaptic homeostasis. Science 326: 1127-1130

Doyle M, Kiebler MA. 2011. Mechanism of dendritic mRNA transport and its role in synaptic tagging. EMBO J 30: 3540-3552.

Driscoll HE, Muraro NI, He M, Baines RA. 2013. Pumilio-2 regulates translation of NAv1.6 to mediate homeostasis of membrane excitability. J Neurosci 33: 9644-9654.

Ehlers MD. 2003. Activity level controls postsynaptic composition and signaling via the ubiquitin-proteasome system. Nat Neurosci 6: 231-242.
Engert F, Bonhoeffer T. 1997. Synapse specificity of long-term potentiation breaks down at short distances. Nature 388: $279-284$.

English CN, Vigers AJ, Jones KR. 2012. Genetic evidence that brain-derived neurotrophic factor mediates competitive interactions between individual cortical neurons. Proc Natl Acad Sci 109: 19456-19461.

Feldmeyer D, Sakmann B. 2000. Synaptic efficacy and reliability of excitatory connections between the principal neurons of the input layer (layer 4) and output layer (layer 5) of the neocortex. J Physiol 525 Pt 1: $31-39$.

Fonseca R, Vabulas RM, Hartl FU, Bonhoeffer T, Nagerl UV. 2006. A balance of protein synthesis and proteasome-dependent degradation determines the maintenance of LTP. Neuron 52: 239-245.

Fortin DA, Srivastava T, Dwarakanath D, Pierre P, Sygaard S, Derkach VA, Soderling TR. 2012. Brain-derived neurotrophic factor activation of CaM-kinase kinase via transient receptor potential canonical channels induces the translation and synaptic incorporation of GluA1-containg calcium permeable AMPA receptors. J Neurosci 32: $8127-8137$.

Frank CA, Kennedy MJ, Goold CP, Marek KW, Davis GW. 2006. Mechanisms underlying the rapid induction and sustained expression of synaptic homeostasis. Neuron 52: 663-677.

Frank CA, Pielage J, Davis GW. 2009. A presynaptic homeostatic signaling system composed of the Eph receptor, ephexin, Cdc42, and CaV2.1 calcium channels. Neuron 61: 556-569.

Frey S, Frey JU. 2008. "Synaptic tagging" and "cross-tagging" and related associative reinforcement processes of functional plasticity as the cellular basis for memory formation. Prog Brain Res 169: 117-143.

Frey U, Morris RGM. 1997. Synaptic tagging and long-term potentiation. Nature 385: 533-536.

Frick A, Magee J, Johnston D. 2004. LTP is accompanied by an enhanced local excitability of pyramidal neuron dendrites. Nat Neurosci 7: $126-135$.

Gainey MA, Hurvitz-Wolff JR, Lambo ME, Turrigiano GG. 2009. Synaptic scaling requires the GluR2 subunit of the AMPA receptor. J Neurosci 29: 6479-6489.

Glanzman DL, Kandel ER, Schacher S. 1990. Target-dependent structural changes accompanying long-term synaptic facilitation in Aplysia neurons. Science 249: 799-802.

Gonzalez-Forero D, Montero F, Garcia-Morales V, Dominguez G, Gomez-Perez L, Garcia Verdugo JM, Moreno-Lopez B. 2012. Endogenous $\rho$-kinase signaling maintains synaptic strength by stabilizing the size of the readily releasable pool of synaptic vesicles. $J$ Neurosci 32: 68-84.

Goold CP, Davis GW. 2007. The BMP ligand Gbb gates the expression of synaptic homeostasis independent of synaptic growth control. Neuron 56: $109-123$.

Govindarajan A, Kelleher RJ, Tonegawa SA. 2006. Clustered plasticity model of long-term memory engrams. Nat Rev Neurosci 7: 575-583.

Grooms SY, Noh KM, Regis R, Bassell GJ, Bryan MK, Carroll RC, Zukin RS. 2006. Activity bidirectionally regulates AMPA receptor mRNA abundance in dendrites of hippocampal neurons. J Neurosci 26: 8339-8351.

Grubb MS, Burrone J. 2010. Activity-dependent relocation of the axon initial segment fine-tunes neuronal excitability. Nature 465: $1070-1074$

Han EB, Stevens CF. 2009. Development regulates a switch between postand presynaptic strengthening in response to activity deprivation. Proc Natl Acad Sci 106: 10817-10822.

Han JH, Kushner SA, Yiu AP, Cole CJ, Brown RA, Neve RL, Guzowski JF, Silva AJ, Josselyn SA. 2007. Neuronal competition and selection during memory formation. Science 316: 457-460.

Harvey CD, Svoboda K. 2007. Locally dynamic synaptic learning rules in pyramidal neuron dendrites. Nature 450: 1195-1200.

Hegde AN, Goldberg AL, Schwartz JH. 1993. Regulatory subunits of cAMP-dependent protein kinases are degraded after conjugation to ubiquitin: A molecular mechanism underlying long-term synaptic plasticity. Proc Natl Acad Sci 90: 7436-7440.

Hernandez AI, Blace N, Crary JF, Serrano PA, Leitges M, Libien JM,

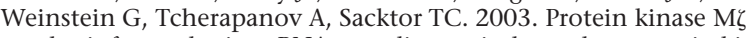
synthesis from a brain mRNA encoding an independent protein kinase C $\zeta$ catalytic domain: Implications for the molecular mechanism of memory. J Biol Chem 278: 40305-40316.

Hou Q, Zhang D, Jarzylo L, Huganir RL, Man HY. 2008. Homeostatic regulation of AMPA receptor expression at single hippocampal synapses. Proc Natl Acad Sci 105: 775-780.

Hou Q, Gilbert J, Man HY. 2011. Homeostatic regulation of AMPA receptor trafficking and degradation by light-controlled single-synaptic activation. Neuron 72: 806-818.

Hruska M, Dalva MN. 2012. Ephrin regulation of synapse formation, function and plasticity. Mol Cell Neurosci 50: 35-44.

Hu JY, Glickman L, Wu F, Schacher S. 2004. Serotonin regulates the secretion and autocrine action of a neuropeptide to activate 
MAPK required for long-term facilitation in Aplysia. Neuron 43: $373-385$.

Hu JY, Baussi O, Levine A, Chen Y, Schacher S. 2011. Persistent long-term synaptic plasticity requires activation of a new signaling pathway by additional stimuli. J Neurosci 31: 8841-8850.

Huang YY, Colino A, Selig DK, Malenka RC. 1992. The influence of prior synaptic activity on the induction of long-term potentiation. Science 255: $730-733$.

Huang T, McDonough CB, Abel T. 2006. Compartmentalized PKA signaling events are required for synaptic tagging and capture during hippocampal late-phase long-term potentiation. Eur J Cell Biol 85: 635-642.

Hubel DH, Wiesel TN. 1970. The period of susceptibility to the physiological effects of unilateral eye closure in kittens. J Physiol 206: 419-436.

Huber KM, Kayser MS, Bear MF. 2000. Role for rapid dendritic protein synthesis in hippocampal mGluR-dependent long-term depression. Science 288: 1254-1257.

Huupponen J, Molchanova SM, Taira T, Lauri SE. 2007. Susceptibility for homeostatic plasticity is down-regulated in parallel with maturation of the rat hippocampal synaptic circuitry. J Physiol 581: 505-514.

Ibata K, Sun Q, Turrigiano GG. 2008. Rapid synaptic scaling induced by changes in postsynaptic firing. Neuron 57: 819-826.

Isaacson JS, Scanziani M. 2011. How inhibition shapes cortical activity. Neuron 72: 231-243.

Ishikawa Y, Tamura H, Shiosaka S. 2011. Diversity of neuropsin (KLK8)-dependent synaptic associativity in the hippocampal pyramidal neuron. J Physiol 589: 3559-3573.

Kandel ER. 2001. The molecular biology of memory storage: A dialogue between genes and synapses. Science 294: 1030-1038.

Kandel ER. 2012. The molecular biology of memory: cAMP, PKA, CRE, CREB-1, CREB-2 and CPEB. Mol Brain 5.14: 1-12.

Kang H, Schuman EM. 1996. A requirement for local protein synthesis in neurotrophin-induced hippocampal synaptic plasticity. Science 273: $1402-1406$.

Karpova A, Mikhaylova M, Thomas U, Knopfel T, Behnisch T. 2006. Involvement of protein synthesis and degradation in long-term potentiation of Schaffer collateral CA1 synapses. J Neurosci 26: 4949-4955.

Kim J, Tsien RW. 2008. Synapse-specific adaptations to inactivity in hippocampal circuits achieve homeostatic gain control while dampening network reverberation. Neuron 58: 925-937.

Lamsa KP, Heeroma JH, Somogyi P, Rusakov DA, Kullmann DM. 2007. Anti-Hebbian long-term potentiation in the hippocampal feedback inhibitory circuit. Science 315: 1262-1266.

Lee HK. 2012. Calcium-permeable AMPA receptors in homeostatic synaptic plasticity. Front Mol Neurosci 5.17: 1-11.

Lin AC, Holt CE. 2007. Local translation and directional steering in axons. EMBO J 26: 3729-3736.

Linden DJ. 1996. A protein synthesis-dependent late phase of cerebellar long-term depression. Neuron 17: 483-490.

Lisman J, Schulman H, Cline H. 2002. The molecular basis of CaMKII function in synaptic and behavioural memory. Nat Rev Neurosci 3: 175-190.

Liu RY, Cleary LJ, Byrne JH. 2011. The requirement for enhanced CREB1 expression in consolidation of long-term synaptic facilitation and long-term excitability in sensory neurons of Aplysia. J Neurosci 31: 6871-6879.

Lu Y, Ji Y, Ganesan S, Schloesser R, Martinowich K, Sun M, Mei F, Chao MV, Lu B. 2011. TrkB as a potential synaptic and behavioral tag. J Neurosci 31: $11762-11771$.

Luscher C, Xia H, Beattie EC, Carroll RC, von Zastrow M, Malenka RC, Nicoll RA. 1999. Role of AMPA receptor cycling in synaptic transmission and plasticity. Neuron 24: 649-658.

Malinow R, Malenka RC. 2002. AMPA receptor trafficking and synaptic plasticity. Annu Rev Neurosci 25: 103-126.

Marder E, Goaillard JM. 2006. Variability, compensation and homeostasis in neuron and network function. Nat Rev Neurosci 7: 563-574.

Martin KC, Casadio A, Zhu H, Yaping E, Rose JC, Chen M, Bailey CH, Kandel ER. 1997. Synapse-specific, long-term facilitation of Aplysia sensory to motor synapses: A function for local protein synthesis in memory storage. Cell 91: 927-938.

Matsuzaki M, Honkura N, Ellis-Davies GC, Kasai H. 2004. Structural basis of long-term potentiation in single dendritic spines. Nature 429: 761-766.

Miller S, Yasuda M, Coats JK, Jones Y, Martone ME, Mayford M. 2002. Disruption of dendritic translation of CaMKIIa impairs stabilization of synaptic plasticity and memory consolidation. Neuron 36: 507-519.

Moccia R, Chen D, Lyles V, Kapuya EEY, Kalachikov S, Spahn CM, Frank J, Kandel ER, Barad M, Martin KC. 2003. An unbiased cDNA library prepared from isolated Aplysia sensory neuron processes is enriched for cytoskeletal and translational mRNAs. J Neurosci 23: 9409-9417.
Montgomery JM, Madison DV. 2004. Discrete synaptic states define a major mechanism of synapse plasticity. Trends Neurosci 27: 744-750.

Nargerot R, Simmers J. 2012. Functional organization and adaptability of a decision-making network in Aplysia. Front Neurosci 6.113: 1-11.

Nelson SB, Turrigiano GG. 2008. Strength through diversity. Neuron 60: $477-482$.

Nissen W, Szabo A, Somogyi J, Somogyi P, Lamsa KP. 2010. Cell type-specific long-term plasticity at glutamatergic synapses onto hippocampal interneurons expressing either parvalbumin or CB1 cannabinoid receptor. J Neurosci 30: 1337-1347.

Okuno H, Akashi K, Ishii Y, Yagishita-Kyo N, Suzuki K, Nonaka M, Kawashima T, Fujii H, Takemoto-Kimura S, Abe M, et al. 2012. Inverse synaptic tagging of inactive synapses via dynamic interaction of Arc/ Arg3.1 with CaMKIIß. Cell 149: 886-898.

O'Leary T, van Rossum MC, Wyllie DJ. 2010. Homeostasis of intrinsic excitability in hippocampal neurones: Dynamics and mechanism of the response to chronic depolarization. J Physiol 588: $157-170$.

Perez-Otano I, Ehlers MD. 2005. Homeostatic plasticity and NMDA receptor trafficking. Trends Neurosci 28: 229-238.

Petrus E, Anguh TT, Pho H, Lee A, Gammon N, Lee HK. 2011. Developmental switch in the polarity of experience-dependent synaptic changes in layer 6 of mouse visual cortex. J Neurophysiol 106: 2499-2505.

Raab-Graham KF, Haddick PC, Jan YN, Jan LY. 2006. Activity and mTOR-dependent suppression of Kv1.1 channel mRNA translation in dendrites. Science 314: 144-148.

Rabinowitch I, Segev I. 2006. The endurance and selectivity of spatial patterns of long-term potentiation/depression in dendrites under homeostatic synaptic plasticity. J Neurosci 26: 13474-13484.

Rabinowitch I, Segev I. 2008. Two opposing plasticity mechanisms pulling a single synapse. Trends Neurosci 31: 377-383.

Ransom A, Cheethaan EJ, Fox K, Sengpiel F. 2012. Homeostatic plasticity mechanisms are required for juvenile, but not adult, ocular dominance plasticity. Proc Natl Acad Sci 109: 1311-1316.

Raynaud F, Janossy A, Dahl J, Bertaso F, Perroy J, Varrauld A, Vidal M, Worley PF, Boeckers TM, Cockaert J, et al. 2013. Shank3-Rich 2 interaction regulates AMPA receptor recycling and synaptic long-term potentiation. J Neurosci 33: 9699-9715.

Redondo RL, Morris RGM. 2011. Making memories last: The synaptic tagging and capture hypothesis. Nat Rev Neurosci 12: 17-30.

Redondo RL, Okuno H, Spooner PA, Frenguelli BG, Bito H, Morris RGM. 2010. Synaptic tagging and capture: Differential role of distinct calcium/calmodulin kinases in protein synthesis-dependent long-term potentiation. J Neurosci 30: 4981-4989.

Reijmers LG, Perkins BL, Matsuo N, Mayford M. 2007. Localization of a stable neural correlate of associative memory. Science 317: $1230-1233$.

Rial Verde EM, Lee-Osbourne J, Worley PF, Malinow R, Cline HT. 2006. Increased expression of the immediate-early gene arc/arg3.1 reduces AMPA receptor-mediated synaptic transmission. Neuron 52: $461-474$.

Roth-Alpermann C, Morris RGM, Korte M, Bonhoeffer T. 2006. Homeostatic shutdown of long-term potentiation in the adult hippocampus. Proc Natl Acad Sci 103: 11039-11044.

Royer S, Pare D. 2003. Conservation of total synaptic weight through balanced synaptic depression and potentiation. Nature $\mathbf{4 2 2}$ : $518-522$

Sajikumar S, Frey JU. 2004. Late-associativity, synaptic tagging, and the role of dopamine during LTP and LTD. Neurobiol Learn Mem 82: $12-25$.

Sajikumar S, Norte M. 2011. Metaplasticity governs compartmentalization of synaptic tagging and capture through brain-derived neurotrophic factor (BDNF) and protein kinase M $\zeta$. Proc Natl Acad Sci 108: $2551-2556$.

Sajikumar S, Navakkode S, Sacktor TC, Frey JU. 2005. Synaptic tagging and crosstagging: The role of protein kinase $\mathrm{M} \zeta$ in maintaining long-term potentiation but not long-term depression. J Neurosci 25: 5750-5756.

Sajikumar S, Navakkode S, Frey JU. 2007. Identification of compartmentand process-specific molecules required for synaptic tagging during long-term potentiation and long-term depression in hippocampal CA1. J Neurosci 27: 5068-5080.

Sanders J, Cowansage K, Baumgartel K, Mayford M. 2012. Elimination of dendritic spines with long-term memory is specific to active circuits. $J$ Neurosci 32: 12570-12578.

Sarid L, Bruno R, Sakmann B, Segev I, Feldmayer D. 2007. Modeling a layer 4-to-layer $2 / 3$ module of a single column in the rat neocortex: Interweaving in vitro and in vivo experimental observations. Proc Natl Acad Sci 104: 16353-16358.

Sarih A, Mirnajafa-Zadeh J, Jinag B, Sohya K, Safari MS, Arami MK, Yanagawa Y, Tsumoto T. 2012. Cell type-specific presynaptic LTP of 
inhibitory synapses on fast-spiking GABAergic neurons in the mouse visual cortex. J Neurosci 32: 13189-13199.

Seeburg DP, Feliu-Mojer M, Gaiottino J, Pak DT, Sheng M. 2008. Critical role of CDK5 and Polo-like kinase 2 in homeostatic synaptic plasticity during elevated activity. Neuron 58: 571-583.

Shepherd JD, Rumbaugh G, Wu J, Chowdhury S, Plath N, Kuhl D, Huganir RL, Worley PF. 2006. Arc/Arg3.1 mediates homeostatic synaptic scaling of AMPA receptors. Neuron 52: 475-484.

Stellwagen D, Malenka RC. 2006. Synaptic scaling mediated by glial TNF- $\alpha$. Nature 440: 1054-1059.

Steward O, Levy WB. 1982. Preferential localization of polyribosomes under the base of dendritic spines in granule cells of the dentate gyrus. $J$ Neurosci 2: 284-291.

Steward O, Wallace CS, Lyford GL, Worley PF. 1998. Synaptic activation causes the mRNA for the IEG Arc to localize selectively near activated postsynaptic sites on dendrites. Neuron 21: 741-751.

Sun ZY, Wu F, Schacher S. 2001. Rapid bidirectional modulation of mRNA expression and export accompany long-term facilitation and depression of Aplysia synapses. J Neurobiol 46: 41-47.

Sutton MA, Wall NR, Aakalu GN, Schuman EM. 2004. Regulation of dendritic protein synthesis by miniature synaptic events. Science 304: 1979-1983.

Sutton MA, Ito HT, Cressy P, Kempf C, Woo JC, Schuman EM. 2006. Miniature neurotransmission stabilizes synaptic function via tonic suppression of local dendritic protein synthesis. Cell 125: 785-799.

Thiagarajan TC, Lindskog M, Tsien RW. 2005. Adaptation to synaptic inactivity in hippocampal neurons. Neuron 47: 725-737.

Turrigiano GG. 2008. The self-tuning neuron: Synaptic scaling of excitatory synapses. Cell 135: 422-435.

Turrigiano GG, Nelson SB. 2004. Homeostatic plasticity in the developing nervous system. Nat Rev Neurosci 5: 97-107.

Turrigiano GG, Leslie KR, Desai NS, Rutherford LC, Nelson SB. 1998. Activity-dependent scaling of quantal amplitude in neocortical neurons. Nature 391: 892-896.

Udagawa T, Swanger SA, Takeuchi K, Kim JH, Nalavadi V, Shin J, Lorenz LJ, Zukin RS, Bassell GJ, Richter JD. 2012. Bidirectional control of mRNA translation and synaptic plasticity by the cytoplasmic polyadenylation complex. Mol Cell 47: 253-266.

Wang Z, Xu NL, Wu CP, Duan S, Poo MM. 2003. Bidirectional changes in spatial dendritic integration accompanying long-term synaptic modifications. Neuron 37: 463-472.

Wang DO, Kim SM, Zhao Y, Hwang H, Miura SK, Sossin WS, Martin KC. 2009. Synapse- and stimulus-specific local translation during long-term neuronal plasticity. Science 324: 1536-1540.

Waung MW, Pfeiffer BE, Nosyreva ED, Ronesi JA, Huber KM. 2008. Rapid translation of Arc/Arg3.1 selectively mediates mGluR-dependent LTD through persistent increases in AMPAR endocytosis rate. Neuron 59: $84-97$.

Wayman GA, Lee YS, Tokumitsu H, Silva A, Soderling TR. 2008. Calmodulin-kinases: Modulators of neuronal development and plasticity. Neuron 59: 914-931.

Wu L, Wells D, Tay J, Mendis D, Abbott MA, Barnitt A, Qhinlan E, Heynen A, Fallon JR, Richter JD. 1998. CPEB-mediated cytoplasmic polyadenylation and the regulation of experience-dependent translation of $\alpha$-CaMKII mRNA at synapses. Neuron 21: 1129-1139.

Young JZ, Isiegas C, Abel T, Nguyen PV. 2006. Metaplasticity of the late-phase of long-term potentiation: A critical role for protein kinase A in synaptic tagging. Eur J Neurosci 23: 1784-1794.

Zecevic D, Wu JY, Cohen LB, London JA, Hopp HP, Falk CX. 1989. Hundreds of neurons in the Aplysia abdominal ganglion are active during the gill-withdrawal reflex. J Neurosci 9: 3681-3689.

Zhang W, Linden DJ. 2003. The other side of the engram: Experience-driven changes in neuronal intrinsic excitability. Nat Rev Neurosci 4: $885-900$.

Zhu H, Wu F, Schacher S. 1997. Site-specific and sensory neuron-dependent increases in postsynaptic glutamate sensitivity accompany serotonin-induced long-term facilitation at Aplysia sensorimotor synapses. J Neurosci 17: 4976-4986.

Received July 10, 2013; accepted in revised form December 12, 2013. 


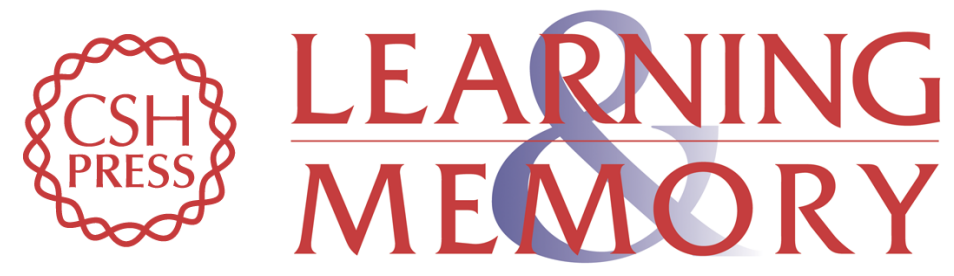

\section{The less things change, the more they are different: contributions of long-term synaptic plasticity and homeostasis to memory}

Samuel Schacher and Jiang-Yuan Hu

Learn. Mem. 2014, 21:

Access the most recent version at doi:10.1101/Im.027326.112

\begin{aligned} & \hline References $\begin{array}{l}\text { This article cites } 139 \text { articles, } 57 \text { of which can be accessed free at: } \\ \text { http://learnmem.cshlp.org/content/21/3/128.full.html\#ref-list-1 }\end{array} \\ & \begin{array}{r}\text { Creative } \\ \text { Commons } \\ \text { License }\end{array} \begin{array}{l}\text { This article is distributed exclusively by Cold Spring Harbor Laboratory Press for the } \\ \text { first } 12 \text { months after the full-issue publication date (see } \\ \text { http://learnmem.cshlp.org/site/misc/terms.xhtml). After } 12 \text { months, it is available under } \\ \text { a Creative Commons License (Attribution-NonCommercial } 3.0 \text { Unported), as } \\ \text { described at http://creativecommons.org/licenses/by-nc/3.0/. }\end{array} \\ & \begin{array}{c}\text { Receive free email alerts when new articles cite this article - sign up in the box at the } \\ \text { top right corner of the article or click here. }\end{array} \\ & \begin{array}{l}\text { Service } \\ \text { terting }\end{array}\end{aligned}$

